\title{
IMPROVING PERFORMANCE OF LOW PRESSURE REVERSE OSMOSIS SYSTEMS BY INTERMITTENT AUTOFLUSHING
}

\author{
I N. Widiasa ${ }^{1 *}$, N. Sinaga ${ }^{2}$, and D. Ariyanti ${ }^{3}$ \\ ${ }^{1}$ Chemical Engineering Department, Diponegoro University \\ ${ }^{2}$ Mechanical Engineering Department, Diponegoro University \\ ${ }^{3}$ Engineering Department, Diponegoro University \\ Jl. Prof. Soedarto, SH. Kampus Tembalang, Semarang, Indonesia, 50239 \\ Email: widiasa_70@yahoo.com
}

\begin{abstract}
Scaling formation on the membrane surface in the form of calcium carbonate, calcium sulphate, silica, and/or magnesium silicate is a main problem of the reverse osmosis (RO) application for upgrading low grade water. Scaling in RO system is generally controlled by softening the feed water, limiting the recovery and/or the addition of antiscalants which is impractical for household RO system. In this work, the feasibility of intermittent autoflushing to prevent scale formation in household RO systems was investigated. All experiments were carried out using commercially available RO membrane (CSM RE-1812LP) which operated for 6 hours under operating pressure $5 \mathrm{~kg} / \mathrm{cm}^{2}$ and total recycle operating mode. Model solution of feed water contain $\mathrm{CaCl}_{2}$ and $\mathrm{NaHCO}_{3}$ were prepared to meet various $\mathrm{LSI}$ values in the range of 0 to 1.5. Duration and interval time of autoflush were in the range of 60 to $15 \mathrm{~s}$ and 5 to 60 min respectively. The results shown that the permeate flux of the system which operated using intermittent autoflushing relatively stable. It is emphasized that intermittent autoflushing may improve the performance of household reverse osmosis systems.
\end{abstract}

Keywords: Autoflushing, scaling, physical cleaning, reverse osmosis

\begin{abstract}
Abstrak
Pembentukan kerak (scaling) pada permukaan membran berupa kerak kalsium karbonat, kalsium sulfat, silika dan atau magnesium silikat merupakan permasalahan utama pada aplikasi sistem membran reverse osmosis (R0) pada proses pemurnian air. Scaling pada sistem RO umumnya dikontrol dengan melakukan pretreatment terhadap air umpan seperti softening, menambahkan zat antiscalant pada saat proses pemisahan serta membatasi tingkat recovery, dimana proses-proses tersebut tidak praktis apabila diaplikasikan pada sistem RO skala rumah tangga. Penelitian ini bertujuan untuk melihat kemungkinan metode intermittent autoflush dapat diaplikasikan untuk menghambat terjadinya scaling pada sistem RO skala rumah tangga. Penelitian ini dilakukan dengan menggunakan satu unit membran spiral wound jenis CSM RE-1812LP yang dioperasikan dengan tekanan operasi $5 \mathrm{~kg} / \mathrm{cm}^{2}$ dan waktu operasi \pm 6 jam. Larutan umpan sintesis dibuat dengan melarutkan $\mathrm{CaCl}_{2}$ dan $\mathrm{NaHCO}_{3}$ hingga nilai LSI mencapai kisaran 0-1,5. Durasi dan interval dari metode intermittent autoflush divariasikan pada kisaran 60-15 detik dan 5-60 menit. Hasil penelitian menunjukkan bahwa fluks permeat relatif stabil pada sistem RO yang menggunakan metode intermittent autoflush. Hal ini menandakan bahwa metode intermittent autoflush ini dimungkinkan untuk meningkatkan kinerja dari sistem RO skala rumah tangga.
\end{abstract}

Kata Kunci: Autoflushing, scaling, physical cleaning, reverse osmosis 


\section{Introduction}

Water is very essential to human life. The improvement standard of living from time to time has increasing the water quality standard that needed by human. In contrast, quality of water in every resource in the world was decline due to industrial growth and human activity. Reverse osmosis (RO) membrane is becoming a common treatment method for contaminated drinking water (Effendi, 2003; Eisenberg and Middlebrooks, 1986; Daigger, 2008). RO is probably best known for its use in desalination projects. However, it is also effective for treating water quality problems in the home.

RO membrane system can reduce the amounts of organics, inorganic, bacteria and particulates that can be found in contaminated drinking water. Even though, RO membrane has limitation, especially once scaling phenomena appear in the system (Fisher et al., 2007; Mustofa, 2007; Song et al., 2003). Scaling defines as precipitation of sparingly soluble salts on membrane surfaces. Scaling can cause permeate flux decline, degradation of salt rejection and permanent damage in membrane which affected membrane performance and membrane life time (Mustofa, 2007; Song et al., 2003; Gloede and Melin, 2007; Tzotzi et al., 2007; Chesters, 2009; Oh et al., 2009).

Generally, scaling is related to feed water characteristic (Wang, 2005). Water resources such as river, lake, basin, well water and brackish water contains inorganic compounds which responsible for scaling. The inorganic compounds include calcium carbonate $\left(\mathrm{CaCO}_{3}\right)$, barium sulfate $\left(\mathrm{BaSO}_{4}\right)$, silica $\left(\mathrm{SiO}_{2}\right)$, and calcium sulfate $\left(\mathrm{CaSO}_{4}\right)$, calcium fluoride $\left(\mathrm{CaF}_{2}\right)$, strontium sulfate, $\left(\mathrm{SrSO}_{4}\right)$ and magnesium hydroxide $\left(\mathrm{Mg}(\mathrm{OH})_{2}\right)$ (Effendi, 2003; Daigger, 2008).

Calcium carbonate scale is the first scale that occurs on the membrane surface (Singh, 2006). Detailed studies on $\mathrm{CaCO}_{3}$ scale formation in membrane systems are limited, such as laboratory procedure for characterization of the $\mathrm{CaCO}_{3}$ scaling propensity of RO feed waters and for evaluating antiscalant effectiveness (Drak et al., 2000); induction time of $\mathrm{CaCO}_{3}$ scale formation during flow in porous media (Stamatakis et al., 2005); and scale formation of $\mathrm{CaCO}_{3}$ in $\mathrm{RO}$ and $\mathrm{NF}$ membranes (Tzotzi et al., 2007).

In the process of separation using RO membrane, there will be an increased concentration of the scaleforming species in the bulk due to permeate withdrawal. This is further enhanced in the region next to the membrane surface by the superimposed effect of concentration polarization; concentration polarization phenomena will lead to saturation and super saturation condition, by the time concentration of sparingly soluble salts exceed their solubility limit. In this condition nuclei will occur and grow (Tzotzi et al., 2007; Wang, 2005).

The ability to predict scaling is an important tool in controlling its occurrence (Song et al., 2003; Tzotzi et al., 2007). The methods that can be used to predict scaling especially for calcium carbonate scale, i.e. langelier saturation index (LSI), stiff davis stability index and ryznar stability index. The common one in practice is langelier saturation index (LSI) which shown the calcium carbonate equilibrium in water by calculate delta between system's $\mathrm{pH}$ and saturation $\mathrm{pH}$ of calcium carbonate (Song et al., 2003).

For controlling scale formation, many methods has been used, such as reducing permeate flux withdrawal during separation process which can reduce the rate of precipitation (Sheikholeslami and Ong, 2003). This method has drawback, quantity of product cannot be maximum. Other method is antiscalant addition (Sagle and Freeman, 2004). This method economically applicable in industrial RO membrane system, but not in household system since the procedure and equipment were very complex.

Apart from above, there is one method called intermittent autoflush. The method is mechanical technique which based on automatic degradation of operating pressure in couple of time. In this time feed water will flush the membrane surface and bring out all components which might be concentrated on the membrane surface (Bray, 1976; Chen et al., 2003; Shon et al., 2007; Anonym, 2008). Intermittent autoflush method did not use chemical agent and automatically worked while separation proceed, also only applicable for low pressure RO membrane. From this point of view intermittent autoflush may be suitable for household RO system. Many inventions related to autoflush system for membrane process such as reverse osmosis system with automatic flushing (Bray, 1976); compact reverse osmosis system with cold water flush (Mora et al., 1992); hydrostatically driven osmotic membrane flush system (Schoenmeyr, 1997); while experimental data 
about the feasibility of intermittent autoflush to prevent $\mathrm{CaCO}_{3}$ scale formation in household RO system still not available on literature.

The scope of this work is two-fold: first to investigate the trend of flux decline due to scaling in various LSI value with full recycle mode in relatively short runs $6 \mathrm{~h}$. A second objective is to examine the effectiveness of intermittent autoflush method (by varying the interval and duration time) in the same household RO system under identical conditions.

\section{Methodology Model Solution}

In this project, bicarbonate model solution was used as feed water by mixing a number of $\mathrm{CaCl}_{2}$ and $\mathrm{NaHCO}_{3}$ (Merck) in $1 \mathrm{~L}$ distilled water. The concentration was varying as mentioned in Table 1.

Table 1. Variation model solution concentration

\begin{tabular}{ccc}
\hline No & $\mathrm{CaCl}_{2}(\mathbf{p p m})$ & $\mathbf{N a H C O}_{3}(\mathbf{p p m})$ \\
\hline 1 & 150 & 227 \\
2 & 200 & 302 \\
3 & 260 & 393 \\
4 & 400 & 605 \\
5 & 800 & 1210 \\
\hline
\end{tabular}

$\mathrm{Ca}^{2+}$ content, $\mathrm{pH}$ and TDS (total dissolved solid) value of model solution were analyzed by EDTA titration method, $\mathrm{pH}$ meter and TDS meter.

\section{Household RO membrane}

All experiments were carried out using commercially available spiral wound RO membrane (CSM RE-1812LP) supplied by Saehan Industries Inc. The RO membrane was made of polyamide with negative surface charge. The membrane was fabricated as thin film composite and configurated as spiral wound. Outer diameter and length of the RO membrane were 1.77 and 11.8 inch, respectively. The membrane system was supported by a diaphragm pump, a feed water tank and a timer as autoflush controller. In the beginning, membrane conditioning was conducted for stabilizing the membrane in total recycle mode during 6 hours at pressure of $5 \mathrm{~kg} / \mathrm{cm}^{2}$ and flowrate of $60 \mathrm{l} / \mathrm{h}$ (see Figure 1).

\section{Experiment}

The aim of the first experiment is to investigate the trend of flux decline due to scaling in various LSI value. The system was operated without intermittent autoflush

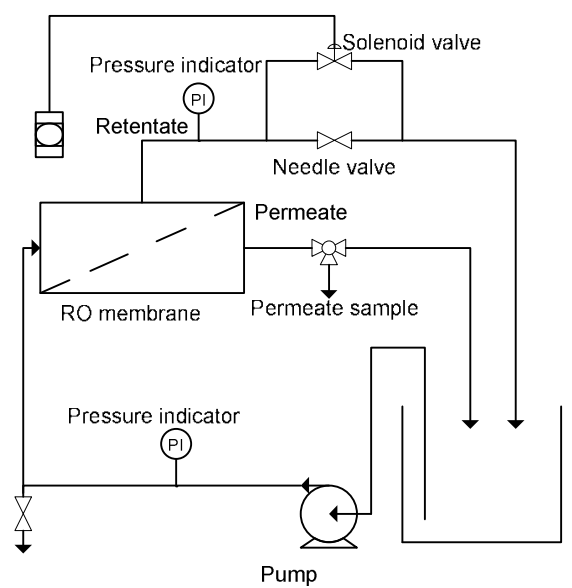

Figure 1. Schematic diagram of the experimental set-up

method using feed water in various LSI value as mentioned in Table 2. The system also operated in total recycle mode during 6 hours at pressure of $5 \mathrm{~kg} / \mathrm{cm}^{2}$ and flow rate of 60 l/h. Sample of permeate was taken every 20 min, for flux analysis.

Table 2. Run without intermittent autoflush method

\begin{tabular}{ccc}
\hline No & LSI & $\begin{array}{c}\text { Run without } \\
\text { autoflush }\end{array}$ \\
\hline 1 & 0 & $\sqrt{ }$ \\
2 & $+0,31$ & $\sqrt{ }$ \\
3 & +0.8 & $\sqrt{ }$ \\
4 & +1.2 & $\sqrt{ }$ \\
5 & +1.5 & $\sqrt{ }$ \\
\hline
\end{tabular}

Table 3. Run with intermittent autoflush method

\begin{tabular}{cccccc}
\hline $\begin{array}{c}\text { Duration } \\
\text { (sec) }\end{array}$ & $\begin{array}{c}\text { Interval } \\
\text { (min) }\end{array}$ & \multicolumn{5}{c}{ LSI Value } & \\
& 5 & $\sqrt{ }$ & $\mathbf{0 , 8}$ & $\mathbf{1 , 2}$ & $\mathbf{1 , 5}$ \\
\hline & 10 & $\sqrt{ }$ & $\sqrt{ }$ & $\sqrt{ }$ & $\sqrt{ }$ \\
& 15 & $\sqrt{ }$ & $\sqrt{ }$ & $\sqrt{ }$ & $\sqrt{ }$ \\
60 & 20 & $\sqrt{ }$ & $\sqrt{ }$ & $\sqrt{ }$ & $\sqrt{ }$ \\
& 25 & $\sqrt{ }$ & $\sqrt{ }$ & $\sqrt{ }$ & $\sqrt{ }$ \\
& 30 & $\sqrt{ }$ & $\sqrt{ }$ & $\sqrt{ }$ & $\sqrt{ }$ \\
& 60 & $\sqrt{ }$ & $\sqrt{ }$ & $\sqrt{ }$ & $\sqrt{ }$ \\
\hline & 5 & $\sqrt{ }$ & $\sqrt{ }$ & $\sqrt{ }$ & $\sqrt{ }$ \\
& 10 & $\sqrt{ }$ & $\sqrt{ }$ & $\sqrt{ }$ & $\sqrt{ }$ \\
30 & 15 & $\sqrt{ }$ & $\sqrt{ }$ & $\sqrt{ }$ & $\sqrt{ }$ \\
& 20 & $\sqrt{ }$ & $\sqrt{ }$ & $\sqrt{ }$ & $\sqrt{ }$ \\
& 25 & $\sqrt{ }$ & $\sqrt{ }$ & $\sqrt{ }$ & $\sqrt{ }$ \\
& 30 & $\sqrt{ }$ & $\sqrt{ }$ & $\sqrt{ }$ & $\sqrt{ }$ \\
& 60 & $\sqrt{ }$ & $\sqrt{ }$ & $\sqrt{ }$ & $\sqrt{ }$ \\
\hline \multirow{4}{*}{15} & 5 & $\sqrt{ }$ & $\sqrt{ }$ & $\sqrt{ }$ & $\sqrt{ }$ \\
& 10 & $\sqrt{ }$ & $\sqrt{ }$ & $\sqrt{ }$ & $\sqrt{ }$ \\
& 15 & $\sqrt{ }$ & $\sqrt{ }$ & $\sqrt{ }$ & $\sqrt{ }$ \\
& 20 & $\sqrt{ }$ & $\sqrt{ }$ & $\sqrt{ }$ & $\sqrt{ }$ \\
& 25 & $\sqrt{ }$ & $\sqrt{ }$ & $\sqrt{ }$ & $\sqrt{ }$ \\
& 30 & $\sqrt{ }$ & $\sqrt{ }$ & $\sqrt{ }$ & $\sqrt{ }$ \\
& 60 & $\sqrt{ }$ & $\sqrt{ }$ & $\sqrt{ }$ & $\sqrt{ }$ \\
\hline & & & & &
\end{tabular}


The second step of the experiment conducted using intermittent autoflush method. The system was run in the variation of two autoflush parameters i.e. duration and interval which is shown in Table 3. Identical condition and the same analysis method also used in this experiment.

Membrane samples were prepared for microscopic observations by cutting one or more small pieces of the scaled membrane and then attaching them to a bronze mount. Scanning electron microscopy (SEM) observations were made after gold sputtering in a JEOL JSM 6063 unit. X-ray micro analysis (EDS) was performed in an OXFORD LINK ISIS 300 system on samples with carbon coating.

\section{Results and Discussion}

Flux decline in various LSI value in the system without intermittent autoflush method

Figure 2 presents flux measurement for different LSI values. In some experiment a small initial increase of the flux was observed. For LSI $=0$ and 0.31 , the trend of flux were stable during operation time, a rather small flux decline in the range of $3-6 \%$ were observed, apparently due to the membrane conditioning (compaction, etc.). The small flux decline in above range was close to $5-8 \%$ which the range of the same phenomena shown in other experiments (Tzotzi et al., 2007).

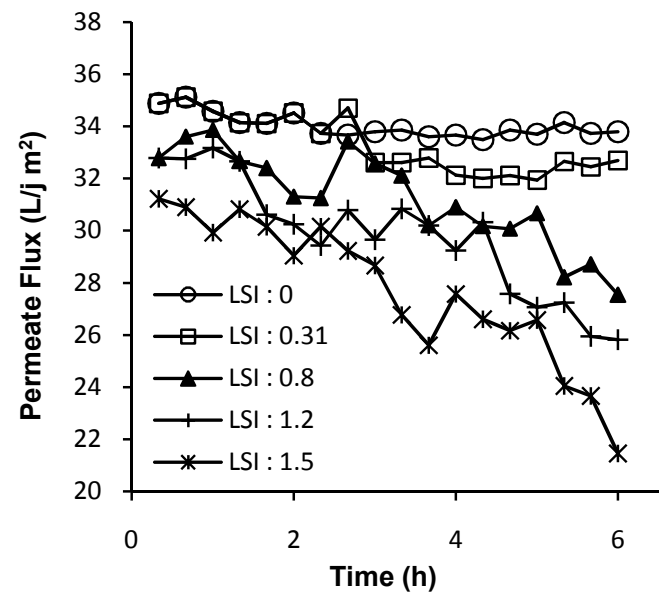

Figure 2. Permeate flux curves in various LSI value $(0-1.5)$ in experiments without intermittent autoflush method

Figure 2 also shown the significant flux decline in LSI $=0.8 ; 1.2$ and 1.5. Permeate flux of LSI 0.8 was decreased up to $16 \%$ and so did the permeate flux of LSI 1.2 and 1.5; both were decreased about $21.23 \%$ and $31.28 \%$ from initial flux. Under the conditions and for the limited duration of these experiments $(6$ hours), it was found that onset scaling in the household RO membrane surface occurs between LSI 0.31-0.8.

From $\mathrm{Ca}^{2+}$ concentration in the feed water point of view also can be stated the same. Figure 3 presents the $\mathrm{Ca}^{2+}$ concentration measurement in the same experiments with above flux measurement.

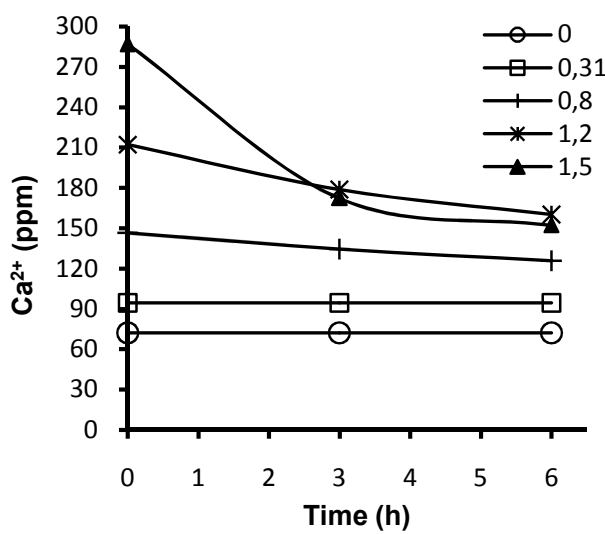

Figure 3. $\mathrm{Ca}^{2+}$ concentration curves in various LSI value $(0-1.5)$ in experiments without intermittent autoflush method

For LSI $=0$ and 0.31 , the $\mathrm{Ca}^{2+}$ concentration were same both in the initial and in the end of experiment. In contrast, the $\mathrm{Ca} 2+$ concentration for $\mathrm{LSI}=0.8 ; 1.2 ; 1.5$ were decreased $14 \%$ up to $46.9 \%$ from initial Ca2+ concentration in the feed water. This data were obviously supported the earlier statement that onset scaling in the household RO membrane surface occurs between LSI 0.31-0.8. The decrease of $\mathrm{Ca}^{2+}$ concentration indicates that the ions were polarized in the membrane surface to form scale and covering the membrane surface which lead to reduction of the available filtration area and permeate flux decline.

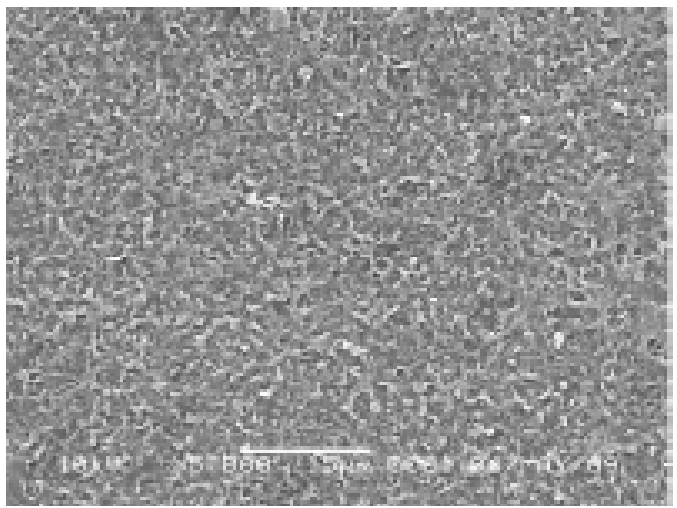

Figure 4. SEM micrograph membrane surface of polyamide free from scale 
The scale formation can also be seen by visual observation in the membrane surface. The micro image of the scale was analyzed using analytical scanning electron microscope (SEM). Figure 4 present membrane surface of polyamide free from scale. While figure 5 and 6 show that there are scale at the membrane surface in the deposit form, after experiments without intermittent autoflush conducted.

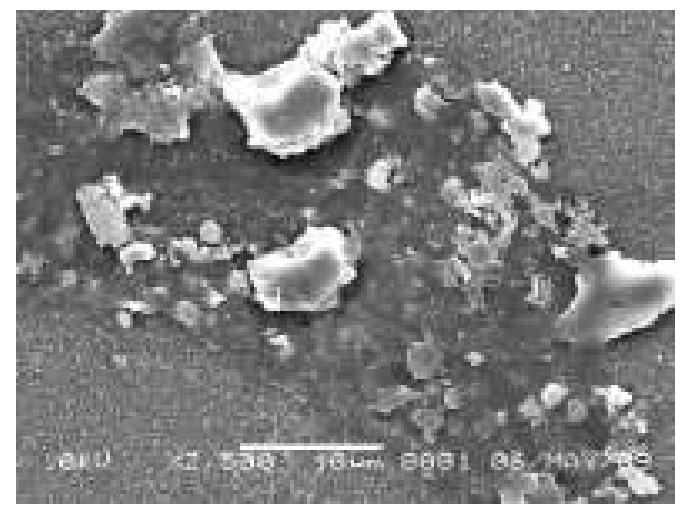

Figure 5. SEM micrograph of scale in deposit form on the membrane surface lateraly

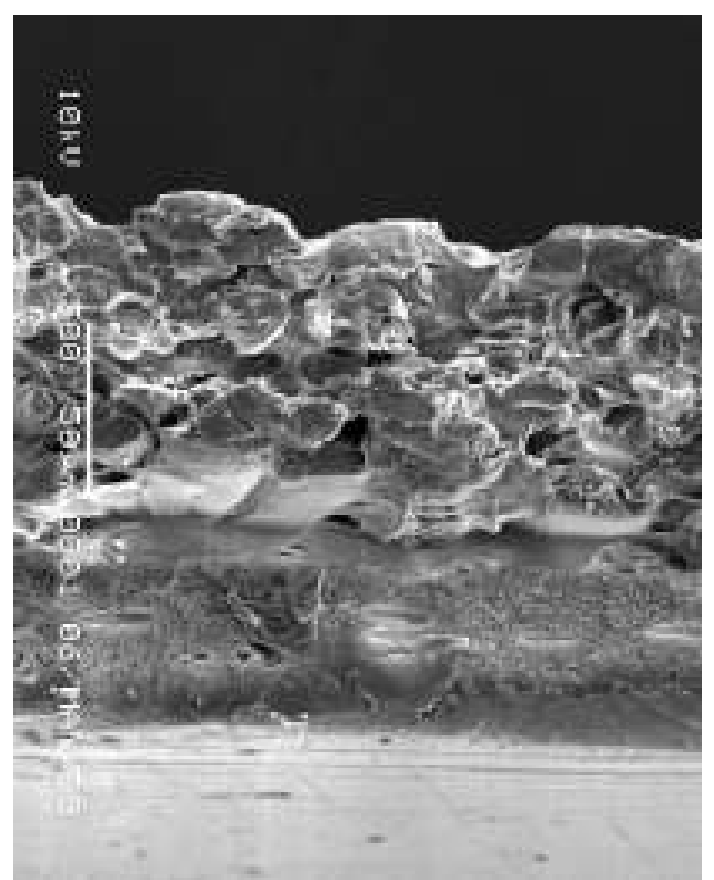

Figure 6. SEM micrograph of scale in deposit form on the membrane surface in cross section point of view

Cake layer scale in the deposit form on the membrane surface was formed due to bulk (homogeneous) crystalization. Bulk (homogeneous) crystalization is one of pathways of scaling mechanism. In this mechanism, crystals formed in the bulk
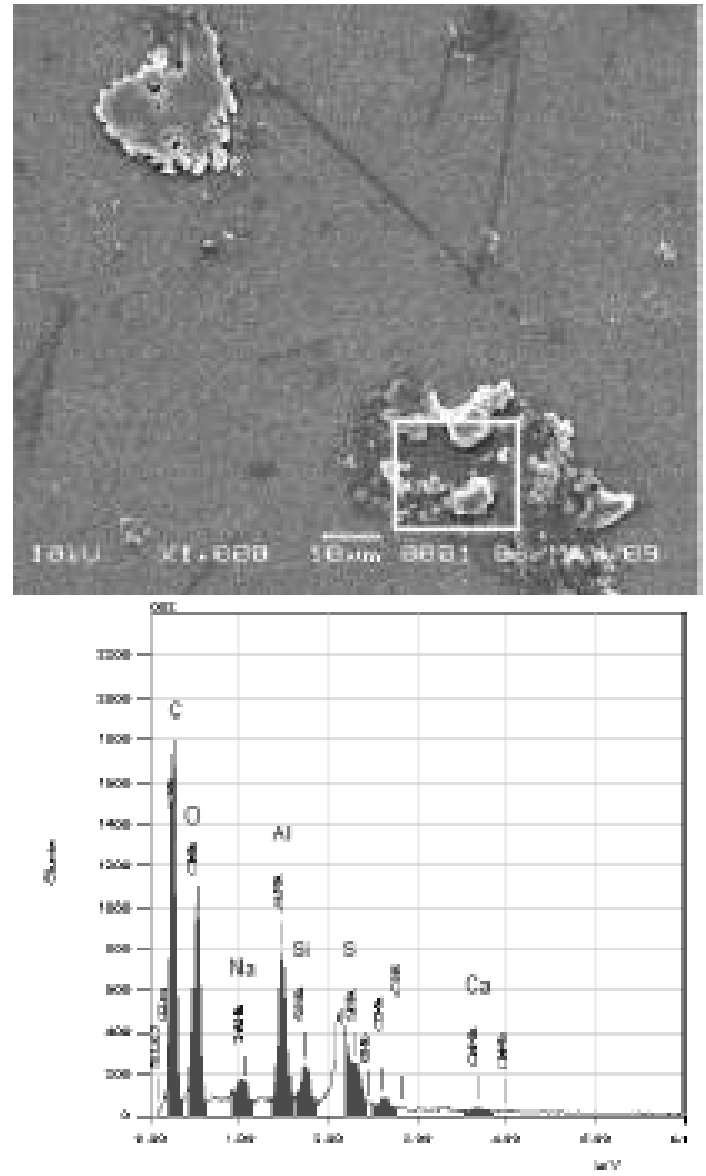

Figure .7 EDS analysis of scale on the membrane surface

mechanism, crystals formed in the bulk solution sediment on the membrane surface leading to flux decline (Oh et al., 2009). The content of scale which is formed on the membrane surface can be analyzed using energy dispersive X-ray spectrometer (EDS). Figure 7 shown the scale which is formed in one spot on the membrane surface and the analysis result of scale components at that zone. EDS analysis shown the peak of $\mathrm{Ca}$ which expressed that there are scale in the form of calcium carbonate on the membrane surface.

Trend of permeate flux in various interval in the system with intermittent autoflush method

A study was also carried out to assess the scale suppression effectiveness of various intermittent autoflush parameter combinations at the same condition. Result from previous section shown that scaling occurs in the membrane surface at LSI value 0.8-1.5. According to the result, trend of permeate flux in various interval in the 
system with intermittent autoflush method were observed in the range of LSI value 0.81.5. Interval is the time between first autoflush process and the next process. The autoflush duration was set for $60 \mathrm{sec}$ operation time and various intervals in the range of 5-60 min. The assessment was made in the terms of monitoring of the permeate flux as well as concentration of $\mathrm{Ca} 2+$ in the feed water. Judging from the evaluation of permeate flux, intermittent autoflush method in the variation of parameter combination tested in the present work appear to be effective in suppressing calcium carbonate scale formation on the membrane surface.

Figure 8, 9 and 10 present the permeate flux measurement for different autoflush interval at LSI value 0.8-1.5. For LSI=0.8 (Figure 8) and LSI=1.2 (Figure 9), there were two tendency observed in both of permeate flux trend. First was in the interval 5-25 min, the permeate flux relatively stable in 37-38 $\mathrm{L} / \mathrm{h} \mathrm{m} \mathrm{m}^{2}$. On the other hand, the second tendency was in the interval 30-60 min, permeate flux seems decline insignificantly in 34-35 L/h m².

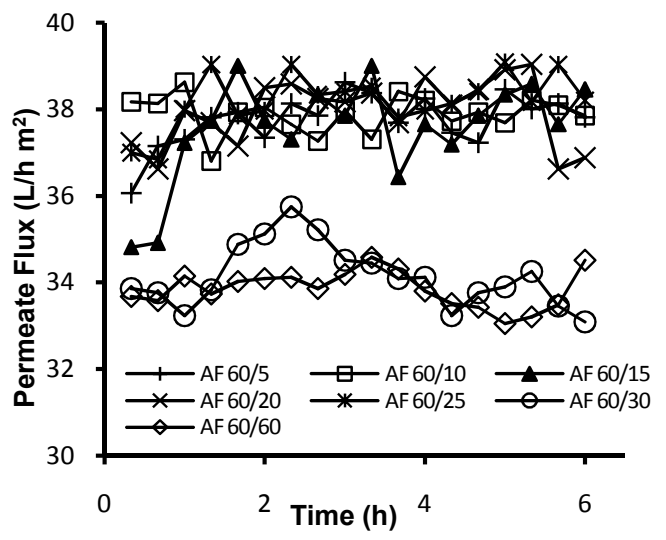

Figure 8. Permeate flux curves in experiments with intermittent autoflush method; LSI $=0.8 ; 60$ sec duration time in various interval (5-60 min)

Even all interval time seems to be effective in suppressing calcium carbonate scale formation in both LSI value 0.8 and 1.2 , but the monitoring of $\mathrm{Ca}^{2+}$ concentration in the feed water during the experiment shown different. $\mathrm{Ca}^{2+}$ concentration in both LSI value 0.8 and 1.2 starts decreasing at the interval 30 min for about $10-14 \%$.

Figure 10 shown the permeate flux measurement for different autoflush interval (5-60 $\mathrm{min})$ at LSI value 1.5. The same tendency observed, First was in the interval 5-
$15 \mathrm{~min}$, the permeate flux relatively stable in 35-36 L/h m2. In contract, the second tendency was in the interval 20-60 min, permeate flux only reach $29-30 \mathrm{~L} / \mathrm{h} \mathrm{m}$. The monitoring result of $\mathrm{Ca}^{2+}$ concentration also shown similar pattern. $\mathrm{Ca}^{2+}$ concentration start decreasing at the interval $20 \mathrm{~min}$ for about $19 \%$.

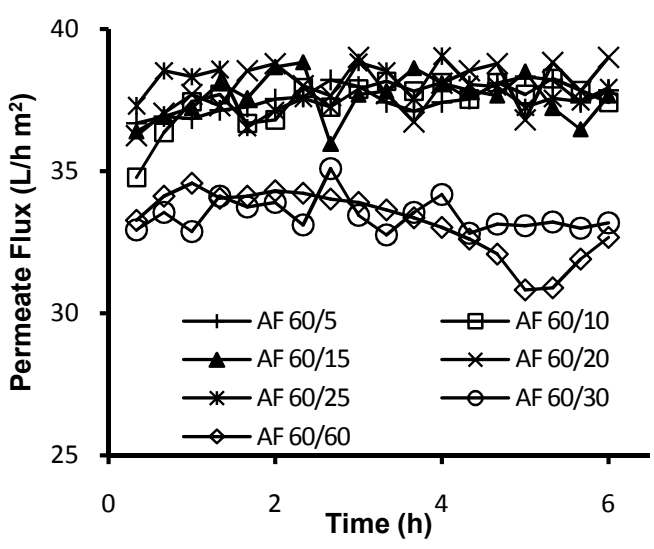

Figure 9. Permeate flux curves in experiments with intermittent autoflush method; LSI=1.2; 60 sec duration time in various interval (5-60 min)

$\mathrm{AF}=$ intermittent autoflush parameter combination (duration (sec)/ (interval (min))

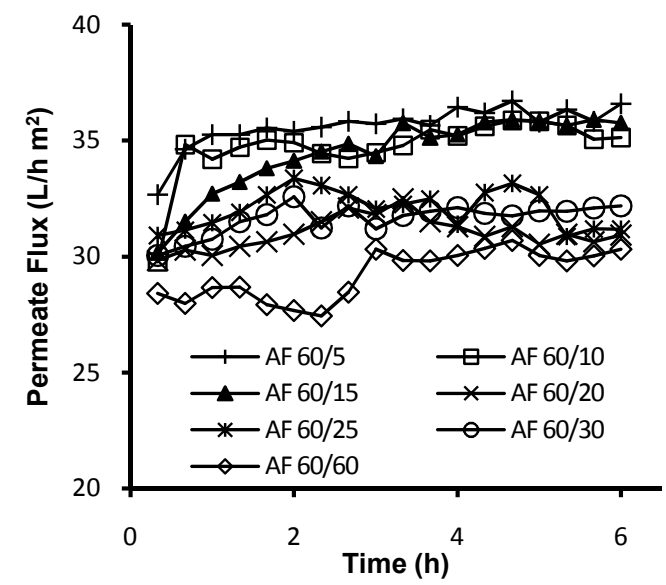

Figure 10. Permeate flux curves in experiments with intermittent autoflush method; LSI=1.5; 60 sec duration time various interval (5-60 min)

The permeate flux decline and decreasing of $\mathrm{Ca}^{2+}$ concentration in the feed water in specific time may be related to the rate of polarization concentration that happen in the membrane system and induction time of calcium carbonate. Such as for LSI 0.8 and 1.2 flux decline and $\mathrm{Ca}^{2+}$ concentration start 
decreasing at the time of $30 \mathrm{~min}$ operation time and for LSI 1.5 at the time of $20 \mathrm{~min}$ operation time. But these relationships need to be observed and prove in the next experiment.

These phenomena indicate that autoflush parameter such as interval was able to stabilizing and improving performance of household reverse osmosis systems at some specific level.

Trend of permeate flux in various duration in the system with intermittent autoflush method

In other experiment which already conducted, conclude that interval and duration of intermittent autoflush method were effected the permeate flux stabilization (Shon et al., 2007). But how far the duration influencing the permeate flux still not available in the literature. Duration is the time when autoflush process conducted. The same assessment was made in the terms of monitoring of the permeate flux.

Figure 11, 12 and 13 presents the permeate flux measurement for different autoflush duration $(60,30$ and $15 \mathrm{sec})$ at LSI value $0.8 ; 1.2 ; 1.5$ and interval time $5 \mathrm{~min}$. All curves were showing the similar phenomena.

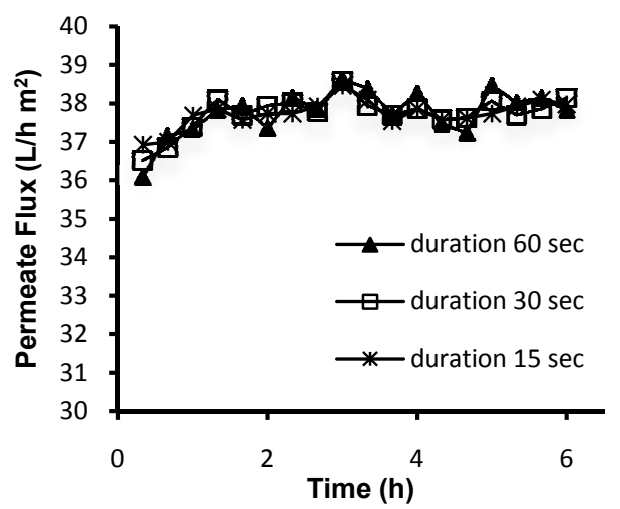

Figure 11. Permeate flux curves in experiments with intermittent autoflush method; LSI=0.8; $5 \mathrm{~min}$ interval time in various duration time $(60-15 \mathrm{sec})$

The experiment which used feed water with LSI value 0.8 , permeate flux was in the range of $37-38 \mathrm{~L} / \mathrm{h} \mathrm{m}^{2}$ in duration time $60 \mathrm{sec}$, $30 \mathrm{sec}$ and also in $15 \mathrm{sec}$. The same was happen in the experiment which used feed water with LSI value 1.2. For $\mathrm{LSI}=1.5$ permeate flux was around 35-36 L/h m², applied the same for all duration time.

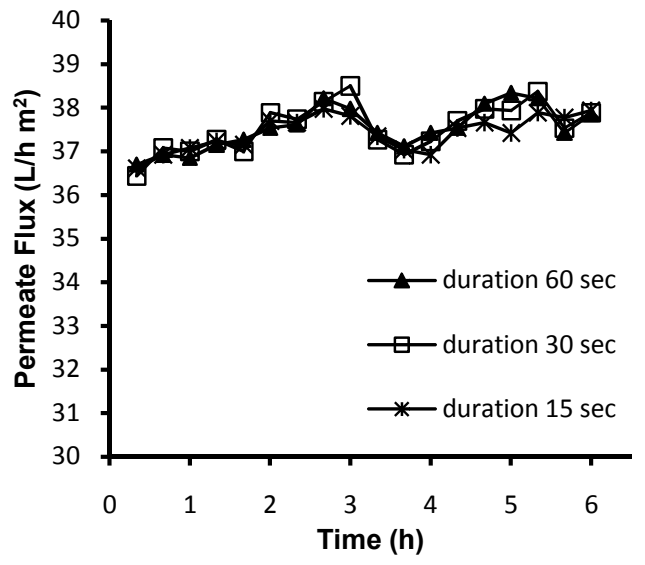

Figure 12. Permeate flux curves in experiments with intermittent autoflush method; $L S I=1.2 ; 5 \mathrm{~min}$ interval time in various duration time $(60-15 \mathrm{sec})$

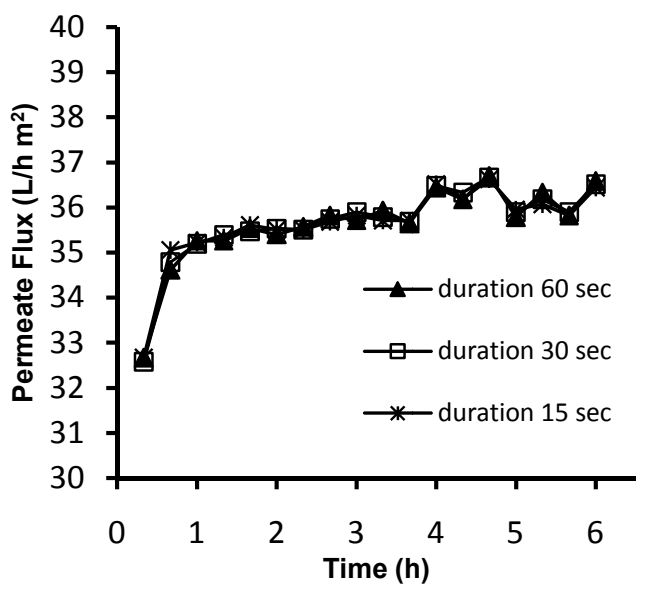

Figure 13. Permeate flux curves in experiments with intermittent autoflush method; $L S I=1.5 ; 5 \mathrm{~min}$ interval time in various duration time $(60-15 \mathrm{sec})$

From the experimental result, the flushing process to depolarized concentration in the membrane and replace membrane which full of concentrate solution that lead to scaling with feed water solution completed at duration time 60, 30 and even 15 sec. More specifically in this experiment, it can be stated that reduction of $15-45 \mathrm{sec}$ duration time to duration time $60 \mathrm{sec}$ still can stabilizing the permeate flux and not showing the significant influence to the permeate flux.

\section{System with and without intermittent autoflush method}

Taking data from previous experiments, the trend of permeate flux curve in the system with and without intermittent 
autoflush method can be compared as shown in the Figure 14.

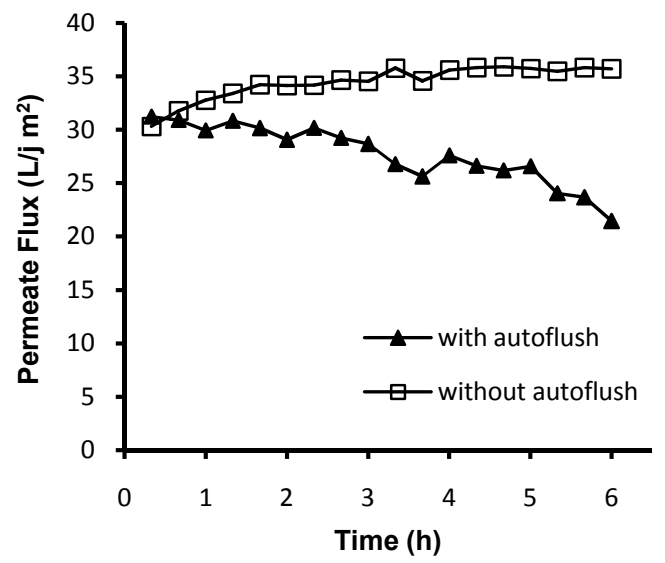

Figure 14. Permeate flux curves in experiments with and without intermittent autoflush method; $L S I=1.5$

Figure 14 definitely supported the statement that intermittent autoflush method is able to stabilizing and improving the performance of household RO membrane system effectively, even in the specific level.

Applying intermittent autoflush method in the household RO membrane system have consequence to removed additional feed water that used for flushing process as drain. But this consequence economically saved, since in household RO membrane system operation, permeate and drain level ratio 1:1 maximum (Anonym, 2004). This is also means for producing $1 \mathrm{~L} / \mathrm{min}$ great quality of water, $1 \mathrm{~L} / \mathrm{min}$ drain has to be removed from the system. Additional removal of feed water that used for flushing process only contributes $1 \%$ to the drain volume.

\section{Determination of the best autoflush interval for various LSI values}

This study was also carried out to determine the best autoflush interval for various LSI values which presented the characteristic of feed water. In the previous discussion already stated that autoflush parameter such as interval was able to stabilizing and improving performance of household reverse osmosis systems at some specific level only.

Data from previous section has shown the best autoflush interval for various LSI values. The data already mentioned in Table 4 and depicted in Figure 15.
Table 4. The best interval for various LSI values

\begin{tabular}{cc}
\hline LSI & Best interval (min) \\
\hline 0.31 & 30 \\
0.8 & 25 \\
1.2 & 25 \\
1.5 & 25
\end{tabular}

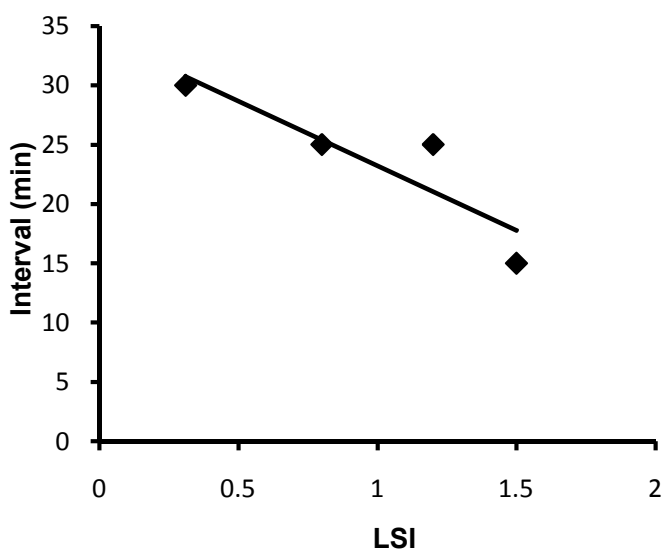

Figure 15. Interval curves in various LSI values; household RO membrane system 5 $\mathrm{kg} / \mathrm{cm}^{2}$ operation pressure

In determining the best autoflush interval for various LSI values, the trend line was described in the linier approach. The linier trend line was used basically from hypothesis that there are limitation where on the one specific LSI value, intermittent autoflush method cannot stabilizing and improving the performance of household RO membrane system. But in this experiment critical LSI value not yet determine.

Equation interval $($ Int $)=(-10,899$ LSI $)$ $+34,132$ can be used to determine the best autoflush interval for various LSI values in household RO membrane system $5 \mathrm{~kg} / \mathrm{cm} 2$ operation pressure application.

\section{Conclusion}

$\mathrm{CaCO}_{3}$ scale formation in the household RO membrane system has been investigated. The permeate flux start to decline and $\mathrm{Ca}_{2+}$ concentration start to decrease in between of feed water with LSI value 0.31-0.8, indicates that the ions were polarized in the membrane surface to form scale and covering the membrane surface which lead to reduction of the available filtration area.

Application of intermittent autoflush method in the household RO membrane system also investigated in terms of influence of interval and duration time. Data from experiments show that autoflush parameter 
such as interval was able to stabilizing and improving performance of household reverse osmosis systems at some specific level. Equation interval $($ Int $)=(-10,899$ LSI $)+$ 34,132 can be used to determine the best autoflush interval for various LSI values in household RO membrane system $5 \mathrm{~kg} / \mathrm{cm}_{2}$ operation pressure application. Other parameter such as duration or the flushing process to depolarized concentration completed at duration time $60 \mathrm{sec}, 30 \mathrm{sec}$ and even $15 \mathrm{sec}$. Or it can be stated that reduction of 15-45 sec duration time to duration time 60 sec still can stabilizing the permeate flux and not showing the significant influence to thepermeate flux.

\section{References}

Anonym, Membrane Cleaning Methods, www.lentech.com, (accessed on November, 2008)

Anonym, Mo Betta Pro Series Water Store Skid, www.mobettawater.com., (accessed March 2009) 2004.

Bray, D. T., Reverse osmosis System with Automatic Flushing, U.S. Patent 3,959,146, 1976.

Chen, J. P.; Kim, S. L.; Ting, Y.P., Optimization of membrane physical and chemical cleaning by a statistically designed approach, Journal of Membrane Science, 2003, Vol. 219(1-2), 2745.

Chesters, S. P., Innovations in the inhibition and cleaning of reverse osmosis membrane scaling and fouling, Desalination, 2009, Vol. 238(1-3), 22-29.

Daigger, G. T., New Approaches and Technologies for Wastewater Management, National Academy of Engineering Publications, 2008, Vol. 38(3), www.nae.edu (accessed on November 22th, 2008)

Drak, A.; Glucina, K.; Busch, M.; Hasson, D.;Laîne, J. M.; Semiat, R., Laboratory Technique for Predicting The Scaling Propensity of RO Feed Waters, Proceedings of the Conference on Membranes in Drinking and Industrial Water Production, Paris, 3-6 October 2000, Vol.2, 483-492, Paris, 2000.
Effendi, H., Telaah Kualitas Air Bagi Pengelolaan Sumber Daya dan Lingkungan Perairan, Edisi ke 3, Kanisius: Yogyakarta, 11, 44-49, 2003.

Eisenberg, T. N.; Middlebrooks, E. J., Reverse Osmosis Treatment of Drinking Water, Butterworths, Boston, 1986.

Fisher, A.; Reisig, J.; Powell, P.; Walker, M., Reverse osmosis (R/O): How it Works, Cooperative Extension, CSREES South State \& Pacific Islands, Regional Water Quality Program, University of Nevada, 2007.

Gloede, M.; Melin, T., Physical aspects of membrane scaling, Desalination, 2007, Vol. 224(1-3), 71-75.

Mora, H. F.; Ohara, R. J.; Hills, A., Compact Reverse osmosis system with cold water flush, U.S. Patent 5,122,265, 1992.

Mustofa, G. M., The Study of Pretreatment Options for Composite Fouling of Reverse osmosis Membrane Used in Water Treatment and Production, Master Thesis, School of Chemical Science and Engineering, University of South Wales, 2007.

Oh, H. J.; Choung, Y. K.; Lee, S.; Choi, J. S.; Hwang, T. M.; Kim, J. H., scale formation in reverse osmosis desalination: model development, Desalination, 2009, Vol. 238(13), 333-346.

Sagle, A.; Freeman, B., Fundamentals of Membranes for Water Treatment, in The Future of Desalination in Texas, Texas Water Development Board, Austin, Texas, 2004, University of Texas at Austin, http://membrane.ces.utexas.edu (accessed October 2007)

Schoenmeyr, I., Hydrosticcaly driven osmotic membrane flush system for a Reverse osmotic water purification system, U.S. Patent 5,658,457, 1997.

Sheikholeslami, R.; Ong, H. W. K., Kinetics and thermodynamics of calcium carbonate and calcium sulfate at salinities up to $1.5 \mathrm{M}$, Desalination, 2003, Vol. 157(1-3), 217-234.

Shon, H. K.; Smith, P. J.; Vigneswaran, S.; Ngo, H. H., Effect of a hydrodynamic cleaning of a cross-flow membrane system with a novel 
automated approach, Desalination, 2007, Vol. 202(1-3), 351-360.

Singh, R., Hybrid membrane systems for water purification: technology systems design and operations, Elsevier Science \& Technology Books: Netherland, 2006, p. 87-88.

Song, L.; Hu, J. Y.; Ong, S. L.; Ng, W. J.; Elimelech, M.; Wilf, M., Performance limitation of the full-scale reverse osmosis process, Journal of Membrane Science, 2003, Vol. 214(2), 239-244.

Stamatakis, E.; Stubos, A.; Palyvoz, J.; Chatzichristos, C.; Muller, J., An improved predictive correlation for the induction time of
$\mathrm{CaCO}_{3}$ scale formation during flow in porous media, Journal of Colloid and Interface Science, 2005, Vol. 286(1), 7-13.

Tzotzi, C.; Pahiadaki, T.; Yiantsios, S. G.; Karabelas, A. J.; Andritsos, N., A study of $\mathrm{CaCO}_{3}$ scale formation and inhibition in $R O$ and $N F$ membrane processes, Desalination, 2007, Vol. 296(1-2), 171-184.

Wang, Y., Composite fouling of calcium sulfate and calcium cabonate in dynamic seawater reverse osmosis unit, Master Thesis, School of Chemical Engineering and Industrial Chemistry, University of New South Wales, 2005. 